\title{
White spot syndrome of Turbinaria peltata in the temperate region of Japan
}

Received: 9 February 2009/Accepted: 10 May 2009/Published online: 5 June 2009

(C) Springer-Verlag 2009
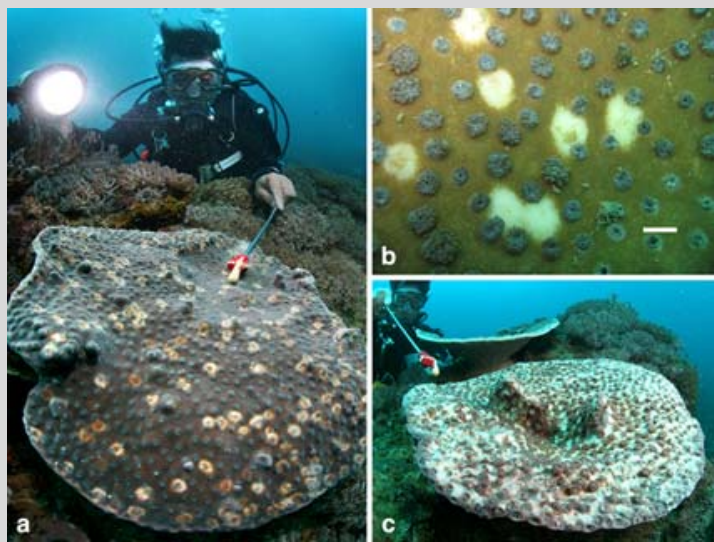

Fig. 1 a White spots on the colony of Turbinaria peltata. b Enlarged view of the spots, (bar: $1 \mathrm{~cm}$ ). $\mathbf{c}$ Fully covered colony by white spots
This study describes new symptoms for Turbinaria in the temperate region of Japan, where coral reefs do not develop (Fig. 1a). Focal bleaching was observed on colonies of Turbinaria peltata (Esper), which is dominant around the study site on Ohshima Island $\left(31^{\circ} 31^{\prime} \mathrm{N}, 131^{\circ} 24^{\prime} \mathrm{E}\right)$ located to the east of the main island of Kyushu, Japan. The bleached spots, where the number of zooxanthellae was decreased ( $29 \%$ of ordinary tissue, Mann-Whitney U-test, $P=0.02, n=4$ ), were roughly circular and about $1 \mathrm{~cm}$ in diameter (Fig. 1b). Almost one-third of the colonies (total of 100 colonies examined) of $T$. peltata were observed to be affected in 2008. The observed spots resemble Porites ulcerative white spot disease (PUWS; Raymundo et al. 2003), but the spots on T. peltata were larger $(1 \mathrm{~cm}$ in diameter) than those in PUWS (3-5 mm). There was no tissue loss, and they appeared exclusively on the coenosac (Fig. 1b). Ultimately, these spots covered the entire surface of the colony (Fig. 1c), which led to gradual necrotic death.

A white syndrome affecting colonies of Turbinaria spp. in tropical regions has been reported from the Great Barrier Reef (Dalton and Smith 2006) and Arabian Gulf (Riegl 2002). In addition, black and yellow band diseases of Turbinaria have been described (Dai et al. 2002). For the temperate corals of Japan, environmentally induced bleaching, predation by crown-of-thorns starfish, and outbreaks of coral-eating gastropods Drupella spp. have been observed

(Fujiwara et al. 2000; Nature Conservation Bureau, Environment Agency 1994). Although the causal agent for these symptoms of T. peltata is still unknown, one should be aware of possible diseases of temperate corals in the northern hemisphere, in addition to bleaching and predators.

Acknowledgments We thank A Iwanaga and the staff of MRT Miyazaki for their support with the sample collection, photography, and diving. Coral sampling in the National Park area was done with the approval of Miyazaki Prefecture, Japan. The underwater photographs (Fig. 1a, c) were taken by Y. Itayama of The Yomiuri Shimbun. This study was supported by the Grants-in-Aid from the Ministry of Education, Science, Sports and Culture, Japan (No. 21510247) (to HY).

\section{References}

Dai C-F, Gang C, Inaba M, Iwao K, Iwase F, Kakuma S (2002) Status of coral reefs in East and North Asia: China, Japan, Korea and Taiwan. In: Wilkinson C (ed) Status of coral reefs of the world: 2002. Australian Institute of Marine Science, Townsville, pp 153-162

Dalton SJ, Smith SDA (2006) Coral disease dynamics at a subtropical location, Solitary Islands Marine Park, eastern Australia. Coral Reefs 25:37-45 Fujiwara S, Shibuno T, Mito K, Nakai T, Sasaki C-F, Dai Y, Chen G (2000) Status of coral reefs of east and north Asia: China, Japan and Taiwan. In: Wilkinson C (ed) Status of coral reefs of the world: 2000. Australian Institute of Marine Science, Townsville, pp 131-140

Nature Conservation Bureau, Environment Agency (1994) The report of the marine biotic environment survey in the 4th national survey on the natural environment. p 349 (in Japanese)

Raymundo LJH, Harvell CD, Reynolds TL (2003) Porites ulcerative white spot disease: description, prevalence, and host range of a new coral disease affecting Indo-Pacific reefs. Dis Aquat Org 56:95-104

Riegl B (2002) Effects of the 1996 and 1998 positive sea-surface temperature anomalies on corals, coral diseases, and fish in the Arabian Gulf (Dubai, UAE). Mar Biol 140:29-40

H. Yamashiro $(\bowtie)$

Department of Bioresources, Okinawa National College of Technology, Henoko 905, Okinawa 905-2192, Japan

e-mail: coral@okinawa-ct.ac.jp

M. Fukuda

Greet divers, Kanamaru-Build. 102 Ichinomiya-machi, Miyazaki city, Miyazaki 880-0854, Japan

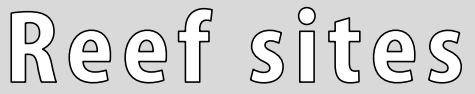

Coral Reefs (2009) 28:893

DOI $10.1007 / \mathrm{s} 00338-009-0514-8$ 